\title{
Critical Nitrogen and Nutritive Index in Cultivars of Cenchrus purpureus (Schumach) Morrone
}

\author{
Vinay-Vadillo, Julio Cesar ${ }^{1}$; Enriquez-Quiroz, Javier Francisco ${ }^{1 *} ;$ Montero-Lagunes, Maribel $^{1}$; \\ Herrera-Sotero, Mónica Yazmín ${ }^{1}$; Mendoza-Pedroza, Sergio Iban²; Bolaños-Aguilar, Eduardo Daniel ${ }^{3}$ \\ ${ }^{1}$ Instituto Nacional de Investigaciones Forestales, Agrícolas y Pecuarias, Campo Experimental La \\ Posta, Veracruz, México. ${ }^{2}$ Colegio de Postgraduados Campus Montecillo, Montecillo, Texcoco. \\ México. ${ }^{3}$ Instituto Nacional de Investigaciones Forestales, Agricolas y Pecuarias, Campo \\ Experimental Huimanguillo, Tabasco, México.
}

*Corresponding Author: enriquez.javier@inifap.gob.mx

\begin{abstract}
Objective: To determine and compare the parameters of the nitrogen curve and the nutritive nitrogen index of cultivars of Cenchrus purpureus with and without nitrogenous fertilization.

Design/Methodology/Approach: Five cultivars of C. purpureus with or without fertilization were evaluated, and the dose was $141 \mathrm{~N}-43 \mathrm{P}-20 \mathrm{~K}$. The grass was harvested every $21 \mathrm{~d}$ with production of dry matter (DM) and nitrogen (N). Growth rates and Critical Nitrogen (Nc) were obtained. The negative power equation with its parameters Nc and the Nitrogen Decrease Coefficient (Cd) were used. The Nutritive Nitrogen Index (NNI) was obtained with the Nc parameter of each curve, divided by the $\mathrm{N}$ content of the cultivar in each sampling. The data were analyzed with a completely randomized design in a factorial arrangement of five (cultivars) and two levels of fertilization.

Results: Nc of 2.6 and a Cd of 0.65 fertilized, and 1.14 of $\mathrm{Nc}$ and 0.68 of $\mathrm{Cd}$ without fertilization, and in turn all of them supplemented the amount of $\mathrm{N}$ for their growth from soil. The NNI was 0.8 for the fertilized cultivars, with classification of excess and sufficient for the first $56 \mathrm{~d}$.
\end{abstract}

Study Limitations/Implications: Variables to determine the availability of water and the balance of soil-plant $\mathrm{N}$ could further expand the knowledge of these tools.

Findings/Conclusions: Parameters obtained such as Nc and NNI help to determine nutritional status of the fodders.

Keywords: Nitrogenous Fertilization, Tropical Fodders, Model Curves.

\section{INTRODUCTION}

The genus Pennisetum South America. However, species of Pennisetum may be found in any country in the tropics and subtropics. It was introduced to Mexico in 1950 (Ramos-Sánchez, 1985), to the state of Veracruz, where it was introduced together with a wide collection of Poaceae for evaluation and selection; one of them was the Pennisetum merkeri, a product of

$$
\text { ctividad: Vol. 13, Num. 12, diciembre. 2020. pp: 83-91. }
$$

Recibido: mayo, 2020. Aceptado: noviembre, 2020.

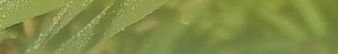


that evaluation. It was recommended for use as cut fodder and released as Zacate Merkeron, which spread throughout the country's southeast. Mexico has a broad diversity of environments, in which the production of perennial Poaceae is highly feasible. These offer high potential for biomass production per surface unit, since it has been documented that the intensely fertilized species P. purpureum (Schumach), syn. Cenchrus purpureus (Schumach) Morrone, Chemisquy et al. (2010), produces large amounts of biomass that can exceed 50 t of dry matter ha ${ }^{-1}$ and year (Calzada et al., 2014; Rueda et al., 2016; Reyes-Castro et al., 2018). Given that the species C. purpureus has a wide potential for biomass production, its preferential use is for cattle feed, whether in grazing, cut, or else as fodder ensilage. In recent years, various cultivars of $C$. purpureus have been introduced to Mexico, from different origin and with scarce technical information, such as: Taiwan, King Grass, CT115, CT-169, Maralfalfa, Mott, Vruckwona, OM-22, Roxo or Purple, and Clone 69, among others. However, these new cultivars are unknown regarding their management, particularly fertilization, and therefore, they require high amounts of nutrients, specifically nitrogen. Nitrogen $(N)$ is essential for crop growth (Tillman et al., 2002) and is considered a limiting factor after water for forage production in meat and dairy production systems in the tropics. The practice of fertilization provides enough $\mathrm{N}$ to reach the potential allowed in appropriate climatic conditions, so that the producers apply amounts that are high or less than that required by the plant to obtain the maximum forage production to ensure that this potential is reached every year, although it is known that excess $N$ reduces the efficiency and can cause environmental problems (Jeuffroy and Meynard, 1997). The management of $\mathrm{N}$ in soil and in fertilizer is an important point for the profitability and sustainability of extensive meat and dairy production systems in the tropics, and for this purpose, methods are required that estimate the critical concentration of $\mathrm{N}$ in the fodders, in order to adjust the dose of $\mathrm{N}$ and the frequency of applications according to their growth potential. Authors such as Justes et al. (1994) developed the methodology to know the nitrogen status during the growth and production of biomass considering the term critical nitrogen $(\mathrm{Nc})$, defined as the minimum concentration of nitrogen required to obtain the maximum growth rate, expressed as $\mathrm{g} N$ per $100 \mathrm{~g}$ in relation to the accumulated dry matter (DM) (t DM ha ${ }^{-1}$ ). This curve is a negative power function that is described as follows:

$$
\% N=a D M^{-b}
$$

Both are specific physiological coefficients where: $a$, is the concentration of $\% \mathrm{~N}$ in the plant when the fodder produces a t DM ha ${ }^{-1}$ and $b$, is the concentration of Nitrogen in the plant when it decreases.

Derived from the previous function, the nutritional status of the fodders is defined and the term Nutritional Nitrogen Index is obtained by its acronym NNI (Colnenne et al., 1998), which can be used as a basis to make decisions about the need to fertilize with $\mathrm{N}$ and its frequency in applications (Lemaire et al., 2008). It is described next:

$$
N N I=N / N C
$$

where $N$ is the current nitrogen concentration of the fodder in percentage of DM and $\mathrm{NC}$ is the critical nitrogen calculated with the negative power function equation.

For $\mathrm{N}$ management in fodders, the $\mathrm{NNI}$ threshold has been defined as follows: Values greater than 1 indicate that $\mathrm{N}$ is in excess, values between 1 and 0.8 indicate that the nutrition is satisfactory, and values below 0.8 indicate $\mathrm{N}$ deficiency, so growth and production are limited (Duru et al., 1997). It has been observed that lower concentrations of $N$ than critical nitrogen $(\mathrm{Nc})$ indicate that growth is restricted by a deficit of $N$, while higher values of $\mathrm{N}$ than $\mathrm{Nc}$ indicate that the contribution of $N$ is in excess (Greenwood et al., 1990). Forage production is related to NNI (Lemaire and Gastal, 1997; Ziadi et al., 2008; Agnusdei et al., 2010). The concept of $\mathrm{Nc}$ and $\mathrm{NNI}$ has been confirmed to be an effective tool for agronomic analysis and interpretation (Lemaire et al., 1997; Lemaire and Meynard, 1997; Gonzalez-Dugo et al., 2005). The objective was to determine and compare the parameters of the nitrogen curve and the nutritive nitrogen index of cultivars of C. purpureus with and without nitrogenous fertilization, to know the nitrogen status in the fodder.

\section{MATERIALS AND METHODS}

The study was carried out in the experimental field "La Posta" in Paso del Toro, Veracruz, located at coordinates $19^{\circ} 00^{\prime} 49^{\prime \prime} \mathrm{N}$ and $96^{\circ} 08^{\prime}$ $19^{\prime \prime} \mathrm{W}$ at $12 \mathrm{~m}$ altitude (INEGI, 2009). The area's climate corresponds to Aw 2 sub-humid tropical (Vidal Zepeda, 2005), with rainfall of $1461 \mathrm{~mm}$, and relative humidity of $77.4 \%$. The average, maximum and minimum temperatures are 25, 35 
and $15^{\circ} \mathrm{C}$. The soils are Vertisol, acidic $\mathrm{pH}$ (5.4), claysandy crumb texture and with organic matter content of $2.6 \%$.

\section{Treatment Design}

The evaluated cultivars were: CT-115, Elefante, Kinggrass, Roxo and Taiwan, all with and without nitrogenous fertilization; fodder samples were carried out every $21 \mathrm{~d}$ for six months in the rainy season. The land was prepared with subsoiling, fallow, double raking and plowing at 80 $\mathrm{cm}$. Two cuttings or stakes of three nodes were used, which were planted every $80 \mathrm{~cm}$ on the embankment of the furrow, ensuring that two of the three nodes were buried at a $45^{\circ}$ angle in relation to the surface. The establishment period was July-August. The sampling area at each cutting date was $5.76 \mathrm{~m}^{2}$, equivalent to three rows, $2.4 \mathrm{~m}$ wide by $2.4 \mathrm{~m}$ long, and eight cuts were made.

At the beginning of the experiment, a uniformity cut was made at $25 \mathrm{~cm}$. The fertilization dose was $141 \mathrm{~N}-43 \mathrm{P}-20 \mathrm{~K}$ (N200 kg of Urea (46\%), $50 \mathrm{~kg}$ of the mixture 18N-46P$00 \mathrm{~K}$, and $\mathrm{K} 200 \mathrm{~kg}$ of the mixture $20 \mathrm{~N}-10 \mathrm{P}-10 \mathrm{~K}$ ) which was dosed in two applications; in the first, eight days after the uniformity cut, the composition was $100 \mathrm{~kg}$ of Urea, $25 \mathrm{~kg}$ of the $18-46-00$ mixture and $100 \mathrm{~kg}$ of the 20-10-10 mixture; in the second, $60 \mathrm{~d}$ after the first application, the rest of the nitrogen, phosphorus and potassium were added. The fodder (green matter) was harvested at a height of $25 \mathrm{~cm}$ from the ground, and every $21 \mathrm{~d}$ of growth.

During sampling, dry matter (DM) production was recorded of the complete plant in each plot, from which a subsample $(300 \mathrm{~g})$ was taken to dry at $55^{\circ} \mathrm{C}$ until reaching constant weight using a forced air oven, and later it was ground. With the registered weights the crop's growth curves and rates were obtained. The amount of nitrogen in the fodder was determined by the Kjeldhal method, in samples of $0.5 \mathrm{~g}$ of complete plants, in the Animal Nutrition Laboratory of CIRGOC-INIFAP, in Campo La Posta, Veracruz. The first cut was made at 14 days of growth and then every $21 \mathrm{~d}$, until $161 \mathrm{~d}$, in the unfertilized plots every $21 \mathrm{~d}$ until $168 \mathrm{~d}$ of age.

\section{Response Variables}

The Nc parameters of the different cultivars of $C$. purpureus were obtained with a non-linear regression analysis using the equation (Justes et al., 1994):

$$
\% N=a D M P^{-b}
$$

where $\% N=$ is the percentage of nitrogen in the total plant in DM; $a=$ is the critical nitrogen parameter, expressed in $\mathrm{g} \mathrm{N} 100 \mathrm{~g}$ of $\mathrm{DM} ; b=$ is the parameter that indicates the dilution of nitrogen as the fodders grow and PDM = is the dry matter production of the fodders at each point or sampling time, and these in turn were adjusted with the Gompertz model to obtain the estimated data in $\mathrm{MS} \mathrm{ha}^{-1}$.

The observed $\mathrm{N}$ percentages of each time in the fodder's growth were adjusted with the Levenberg-Marquart algorithm, and the Kaleidagraph ${ }^{\circledR}$ v3.0 software was used. The NNI of the fodders at each time of growth was determined for each repetition, dividing the amount of nitrogen observed at each time of growth or sampling and the parameter of $\mathrm{Nc}$ determined with the equation defined above.

The growth rate was calculated in $\mathrm{kg} D M \mathrm{ha}^{-1} \mathrm{~d}^{-1}$, with the DM production data estimated with the Gompertz model in the fodder's ages, with the following equation:

$$
T C=\frac{M S P_{t 2}-M S P_{t 1}}{T 2-T 1}
$$

where $T C=$ Growth rate in $\mathrm{kg} D M \mathrm{ha}^{-1} \mathrm{~d}^{-1}, \mathrm{MSP}_{\mathrm{t} 2}=$ Dry matter present in time 2, $\mathrm{kg} \mathrm{DM} \mathrm{ha}^{-1}, \mathrm{MSP}_{\mathrm{t1}}=$ Dry matter present in time 1, $\mathrm{kg} \mathrm{DM} \mathrm{ha}^{-1}, \mathrm{T2}=$ end time, $\mathrm{T1}$ $=$ initial time.

\section{Experimental Design and Statistical Analysis}

The parameters obtained from the nitrogen curves of each fodder by repetition $a=N c$ and $b=C d$, as well as the coefficient of adjustment, were analyzed in an ANOVA in a completely randomized design in a factorial arrangement of $5 \times 2$ :

$$
Y_{i j k}=\mu+A_{j}+B_{j}+A B_{i j}+\varepsilon_{i j k}
$$

where factor $A$ was the five fodders, factor $B$ the application or not of nitrogen fertilizer, and $A B$ the interaction. The data were analyzed with the MINITAB software version 17 in the GLM procedure. The means comparison was carried out with Tukey's test at an alpha of $0.05 \%$. 


\section{RESULTS AND DISCUSSION}

Table 1 shows the results of the data adjustment of the nitrogen percentages in the plant and DM production, during growth every $21 \mathrm{~d}$ and up to $168 \mathrm{~d}$ of age of the $C$. purpureus cultivars, with the negative power function equation of the parameters $\mathrm{Nc}, \mathrm{Cd}$ and $\mathrm{R}^{2}$. The Nc values did not show a difference $(P \geq 0.05)$ between the studied cultivars; these are found in an interval between 1.85 and $2.22 \mathrm{~g}$ of $\mathrm{N}$ per $100 \mathrm{~g} \mathrm{DM}$, necessary to produce $1.0 \mathrm{t} \mathrm{DM} \mathrm{ha}^{-1}$. In relation to the coefficients of $N$, no differences $(P \geq 0.05)$ were found between the cultivars; however, CT-115 and King Grass showed high negative rates of nitrogen dilution through growth with $73.5 \%$, while the Roxo cultivar presented negative rates of less than $57.6 \%$, that is, its decrease is very fast, which indicates that the percentage of $N$ decreases drastically in these fodders. Nc values of 2.5 and $2.78 \mathrm{~g}$ of $\mathrm{N}$ per $100 \mathrm{~g}$ DM have been reported for Brachiaria humidicola and Brachiaria humidicola × Brachiaria ruziziensis (Juárez, 2005). In this regard, Duru et al. (1997) determined that the Nc for tropical fodders under non-limiting conditions of water and nitrogen is $3.6 \mathrm{~g}$ of $\mathrm{N}$ per $100 \mathrm{~g}$ DM and a nitrogen coefficient of 34\%; in turn, Lemaire and Salette (1984 a, b) and Lemaire et al. (1985) demonstrated that tropical fodders decrease Nc as DM production increases.

\section{Nitrogenous Fertilization Effect}

Table 2 shows the effect of fertilization on the parameters of the nitrogen curve in C. purpureus cultivars, which

presented differences $(P \leq 0.05)$, for $N c$, but not for $\mathrm{Cd}$. Nc values of $2.63 \mathrm{~g} \mathrm{~N}$ per $100 \mathrm{~g}$ DM represent the minimum amount necessary to produce one t DM ha ${ }^{-1}$ for fodders that were fertilized with doses of $141 \mathrm{~kg}$ of $\mathrm{N}$ $\mathrm{ha}^{-1}$, whereas for unfertilized fodders, it was 1.42. This decrease is possibly due to the fact that the organic matter content in the soil was not sufficient and would be limited by the lack of water. Juárez et al. (2004) reported a concentration of $\mathrm{Nc}$ of 2.9 with a fertilization dose of $200 \mathrm{~kg}$ of $\mathrm{N} \mathrm{ha}^{-1}$ and 2.6 for the unfertilized, for species of Brachiaria sp., in rainfed conditions and soil rich in organic matter.

\section{Growth Rate and Nitrogen Curves of Cultivars}

Figures 1, 2, 3, 4, and 5 show the growth rate behavior and the nitrogen curve of cultivars C. purpureus with and without fertilization.

\section{Cultivar CT-115}

It is observed that the effect of nitrogenous fertilization on the maximum growth rate was $112 \mathrm{~kg} \mathrm{DM} \mathrm{ha}^{-1}$ day $^{-1}$ and was reached at $35 \mathrm{~d}$ of age, with the production of $3,920 \mathrm{~kg}$ DM (Figure 1). In addition, with the adjustment of the nitrogen curve, an Nc content of $2.62 \mathrm{~g}$ of $\mathrm{N}$ per $100 \mathrm{~g} \mathrm{DM}$ necessary to produce $1.0 \mathrm{t}$ of $\mathrm{DM} \mathrm{ha}^{-1}$ was obtained, for a DM production interval of 1 to 8 t of DM $\mathrm{ha}^{-1}$ (Figure 1). On the contrary, without fertilization, this cultivar showed a growth rate three times lower, of $44 \mathrm{~kg} \mathrm{DM} \mathrm{d}^{-1}$, presenting its peak at $42 \mathrm{~d}$ of age and requiring $1.54 \mathrm{~g}$ of $\mathrm{N}$ per $100 \mathrm{~g} \mathrm{DM} \mathrm{ha}^{-1}$ day $^{-1}$ to produce only $1,800 \mathrm{~kg}$ DM

Table 1. Effect of the cultivar on the parameters and goodness of fit of the nitrogen curve during its growth, up to 168 days of five fodder genotypes.

\begin{tabular}{l|l|l|l|l|l|l|l}
\multicolumn{1}{c|}{ Factor A } & $\mathrm{N}$ & $\mathrm{NC}$ & SEM & Cd & SEM & $\mathrm{R}^{2}$ & SEM \\
\hline CT-115 & 6 & $2.080^{\mathrm{a}}$ & 0.308 & $-0.735^{\mathrm{a}}$ & 0.057 & $0.965^{\mathrm{a}}$ & 0.011 \\
\hline Elephant & 4 & $2.220^{\mathrm{a}}$ & 0.377 & $-0.656^{\mathrm{a}}$ & 0.070 & $0.979^{\mathrm{a}}$ & 0.013 \\
\hline King grass & 5 & $1.851^{\mathrm{a}}$ & 0.344 & $-0.736^{\mathrm{a}}$ & 0.064 & $0.977^{\mathrm{a}}$ & 0.012 \\
\hline Roxo & 6 & $2.001^{\mathrm{a}}$ & 0.308 & $-0.576^{\mathrm{a}}$ & 0.057 & $0.986^{\mathrm{a}}$ & 0.011 \\
\hline Taiwan & 5 & $1.961^{\mathrm{a}}$ & 0.344 & $-0.623^{\mathrm{a}}$ & 0.064 & $0.979^{\mathrm{a}}$ & 0.012 \\
\hline
\end{tabular}

$N=$ number of observations; $N c=$ Critical Nitrogen; $C d=$ Nitrogen Coefficient; $R^{2}=$ Goodness of fit; $\mathrm{SEM}=$ Standard error of the mean; Different literals are statistically significant (Tukey; $\mathrm{P} \leq 0.05$ ).

\begin{tabular}{|c|c|c|c|c|c|c|c|}
\hline Factor B & $\mathrm{N}$ & Nc & SEM & $\mathrm{Cd}$ & SEM & $\mathrm{R}^{2}$ & SEM \\
\hline Fertilized & 14 & $2.627^{a}$ & 0.204 & $-0.645^{a}$ & 0.038 & $0.977^{a}$ & 0.007 \\
\hline No Fertilized & 12 & $1.419^{b}$ & 0.222 & $-0.686^{a}$ & 0.041 & $0.977^{a}$ & 0.008 \\
\hline
\end{tabular}

$\mathrm{N}=$ number of observations; $\mathrm{Nc}=$ Critical Nitrogen; $\mathrm{Cd}=$ Nitrogen Coefficient; Goodness of fit $\mathrm{R}^{2}$; SEM = Standard error of the mean; Different letters are statistically significant (Tukey; $P \leq 0.05)$. $\mathrm{ha}^{-1}$ at $42 \mathrm{~d}$. In other words, this cultivar showed rapid growth by only providing $65 \%$ of the nitrogenous fertilization at the beginning, plus the soil content, requiring $102 \mathrm{~kg}$ of $\mathrm{N}$ ha ${ }^{-1}$ to produce 4 t of DM, with an efficiency of $72 \%$ of the fertilizer; this suggests that the second portion of the nitrogenous fertilization (35\% remaining) had no effect on the maximum growth rate, possibly due to the efficiency resulting from the effect of the cultivar. In this case, a fertilization frequency appropriate to its growth is suggested. 

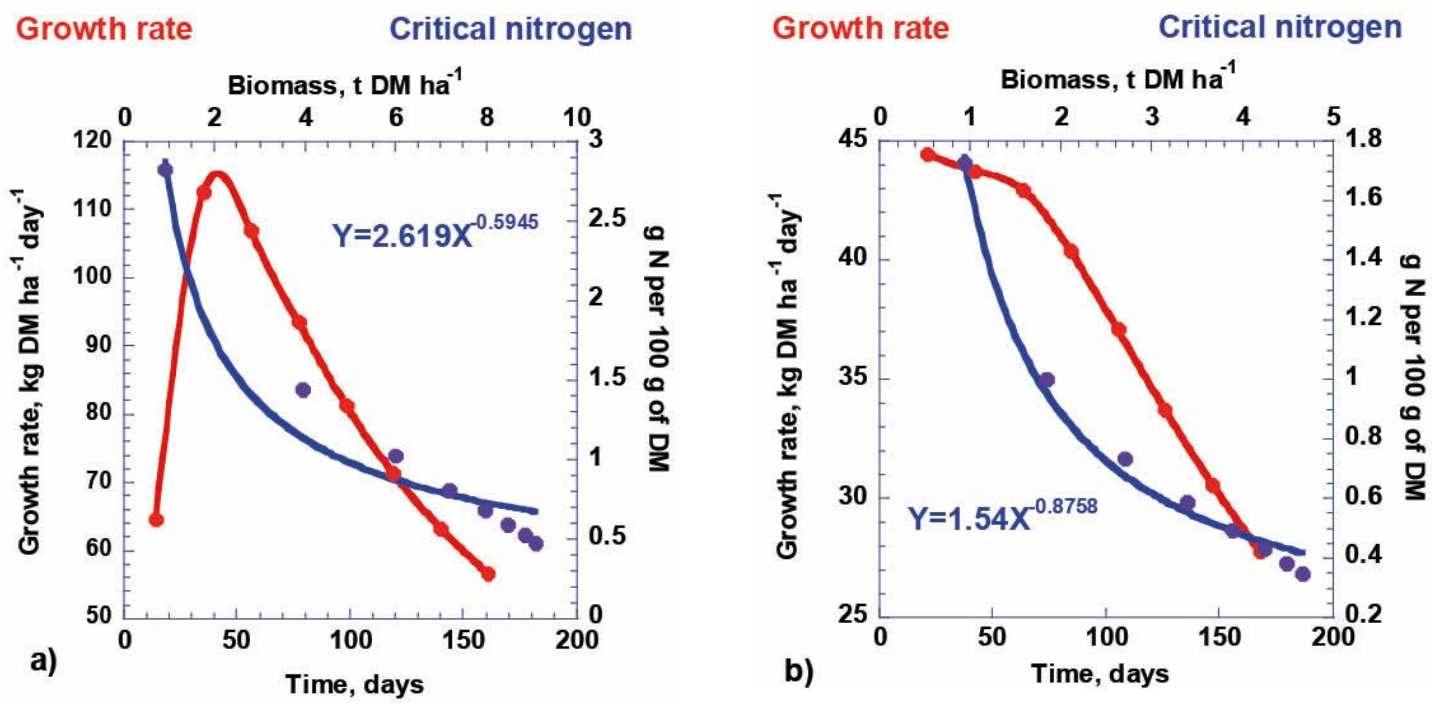

Figure 1. Growth rate and Nc of cultivar CT-115: a) Fertilized b) Not Fertilized.

\section{Cultivar Elefante}

The fertilized cultivar Elefante used $2.6 \mathrm{~g}$ of $\mathrm{N}$ per 100 g of DM to produce 1.0 t of DM ha ${ }^{-1}$ similar to cultivar CT-115, but required $149 \mathrm{~kg}$ of $\mathrm{N} \mathrm{ha}^{-1}$ to produce 5,700 $\mathrm{kg}$ of DM at its maximum peak at $56 \mathrm{~d}$ of age, with a growth rate of $102 \mathrm{~kg}$ of DM ha ${ }^{-1}$ day $^{-1}$ (Figure 2a). A similar situation occurred with the unfertilized control in CT-115, with only $1,828 \mathrm{~g}$ of $\mathrm{N}$ per $100 \mathrm{~g}$ DM per $\mathrm{t}$ of $\mathrm{DM} \mathrm{ha}{ }^{-1}$, resulting in this cultivar extracting nitrogen from the soil, making the latter poorer at the expense of increasing production of DM ha ${ }^{-1}$ and with an efficiency of nitrogen use of $87 \%$ (Figure $2 b$ ).

\section{Cultivar King Grass}

The growth rate of fertilized King Grass was $56 \mathrm{~kg}$ DM $\mathrm{ha}^{-1}$ day $^{-1}$ against $27.7 \mathrm{~kg} \mathrm{DM} \mathrm{ha}{ }^{-1}$ day $^{-1}$ without

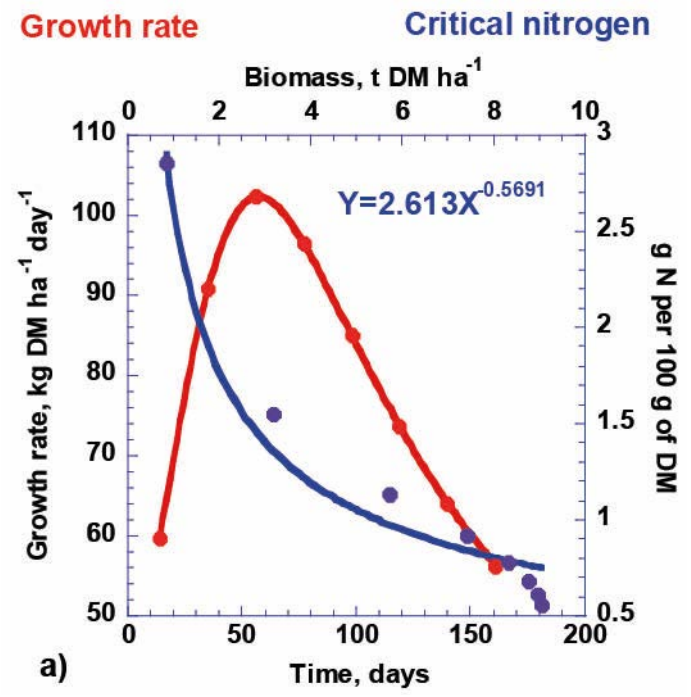

nitrogenous fertilization (Figure 3b). A maximum peak of production of $4,300 \mathrm{~kg} \mathrm{DM} \mathrm{ha} \mathrm{k}^{-1}$ was observed at $77 \mathrm{~d}$ of age and $1,749 \mathrm{~kg} \mathrm{DM} \mathrm{ha}^{-1}$ at $63 \mathrm{~d}$ of age, respectively. With Nc values of 2.62 and $1.08 \mathrm{~g}$ of $\mathrm{N}$ per $100 \mathrm{~g}$ of DM, for fertilized and unfertilized, respectively. For fertilized King Grass, $113 \mathrm{~kg}$ of $\mathrm{N}$ ha ${ }^{-1}$ were required, and for this same cultivar without fertilization only 18.9 $\mathrm{kg}$ of $\mathrm{N} \mathrm{ha}^{-1}$ to obtain its maximum DM production. In both cases, the percentage of nitrogen decreases at a rate of $69 \%$ in the fodder. On the other hand, with the contribution of $100 \%$ of nitrogen in two applications as fertilizer, it seems that there was an effect on the production peak, since the second application of nitrogen (35\% of the $141 \mathrm{~kg}$ ) was carried out after $56 \mathrm{~d}$ of regrowth. The efficiency of nitrogen use against the soil content was $83.4 \%$.

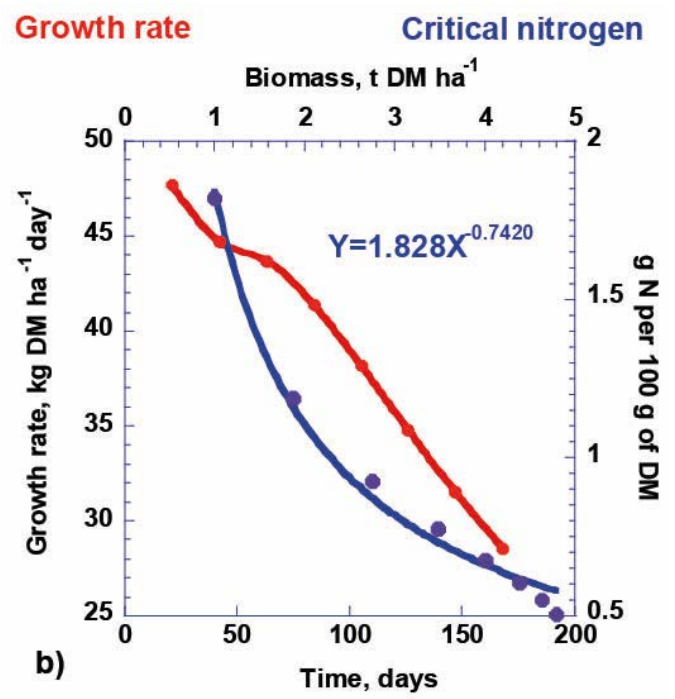

Figure 2. Growth rate and Nc of cultivar Elefante: a) Fertilized b) Not Fertilized. 
Growth rate

Critical nitrogen

Biomass, t DM ha ${ }^{-1}$

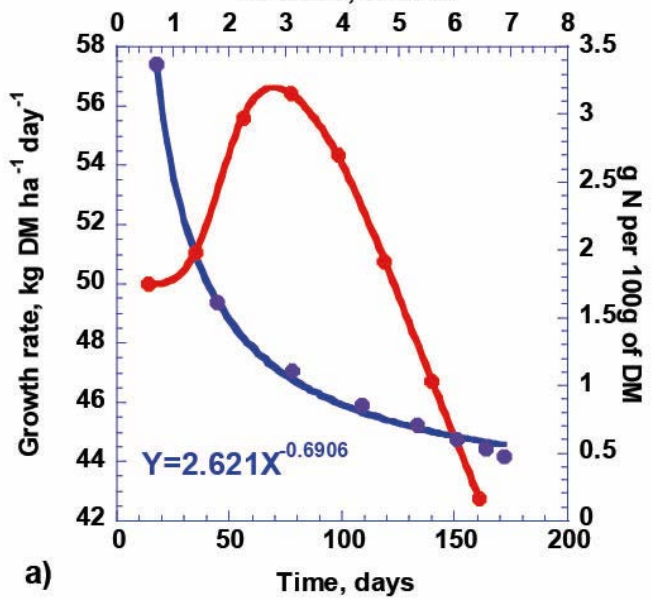

Growth rate Critical nitrogen

Biomass, $\mathrm{t}$ DM ha ${ }^{-1}$

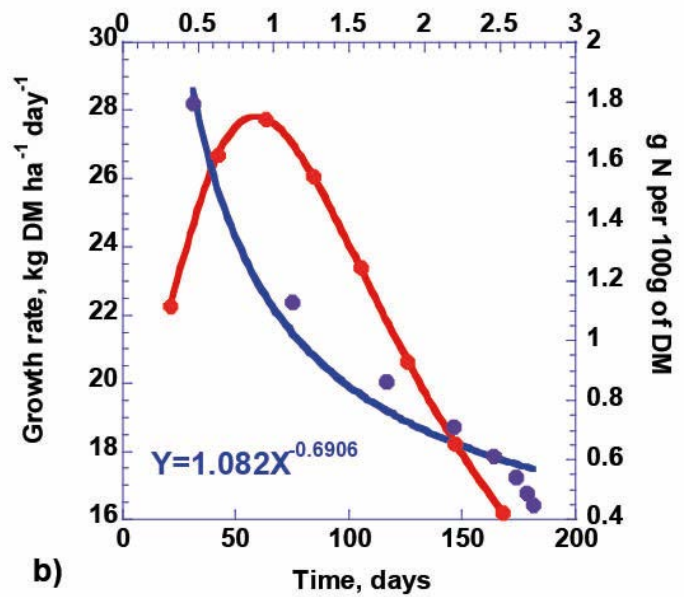

Figure 3. Growth rate and Nc of the cultivar King Grass: a) Fertilized b) Not Fertilized

\section{Cultivar Roxo}

The cultivar Roxo presented a higher growth rate compared to the cultivar King Grass of $76 \mathrm{~kg} \mathrm{DM} \mathrm{ha}^{-1}$ day $^{-1}$ when fertilized and $38.5 \mathrm{~kg} \mathrm{DM} \mathrm{ha}^{-1}$ day $^{-1}$ without fertilizing, at 77 and $63 \mathrm{~d}$ of age respectively. The Nc values were 2.65 and $1.35 \mathrm{~g}$ of $\mathrm{N}$ per $100 \mathrm{~g}$ of DM, fertilized and unfertilized, respectively; therefore, it required a greater amount of nitrogen (155 $\mathrm{kg} \mathrm{N} \mathrm{ha}^{-1}$ ) to produce 5,844 and $2,425 \mathrm{~kg}$ of DM respectively. The efficient use of nitrogen was close to $78 \%$, so the fertilization dose was not enough, since nitrogen was extracted from the soil.

\section{Cultivar Taiwan}

The fertilized cultivar Taiwan presented the highest production of DM ha ${ }^{-1}$ compared to the previously mentioned cultivars. With production of $6,314 \mathrm{~kg}$ of DM $\mathrm{ha}^{-1}$ at $77 \mathrm{~d}$, in which it reached its maximum growth rate with $82.72 \mathrm{~kg}$ of $\mathrm{DM} \mathrm{ha}{ }^{-1} \mathrm{day}^{-1}$. The $\mathrm{Nc}$ was similar to the cultivars with $2.6 \mathrm{~g}$ of $\mathrm{N}$ per $100 \mathrm{~g}$ of DM in a production of $1.0 \mathrm{t} \mathrm{DM} \mathrm{ha}^{-1}$, but when this cultivar did not receive nitrogenous fertilization, its production decreased by $73 \%\left(1,700 \mathrm{~kg}\right.$ of $\left.\mathrm{DM} \mathrm{ha} \mathrm{a}^{-1}\right)$. Its growth rate was reduced to half (40.5 $\mathrm{kg} \mathrm{DM} \mathrm{ha}^{-1}$ day $^{-1}$ ) and its Nc content was $1.29 \mathrm{~g}$ of $\mathrm{N}$ per $100 \mathrm{~g}$ of DM. The efficiency of the use of nitrogen was $86 \%$ and showed balance in the nitrogen consumption of the soil, that is, the dose of nitrogenous fertilization was sufficient to grow and obtain these fodder productions.

\section{N, Nc, NNI Parameters in Cultivars}

In general, when the evaluated cultivars are fertilized with doses of $141 \mathrm{~kg}$ of $\mathrm{N} \mathrm{ha}^{-1}$ in two applications and

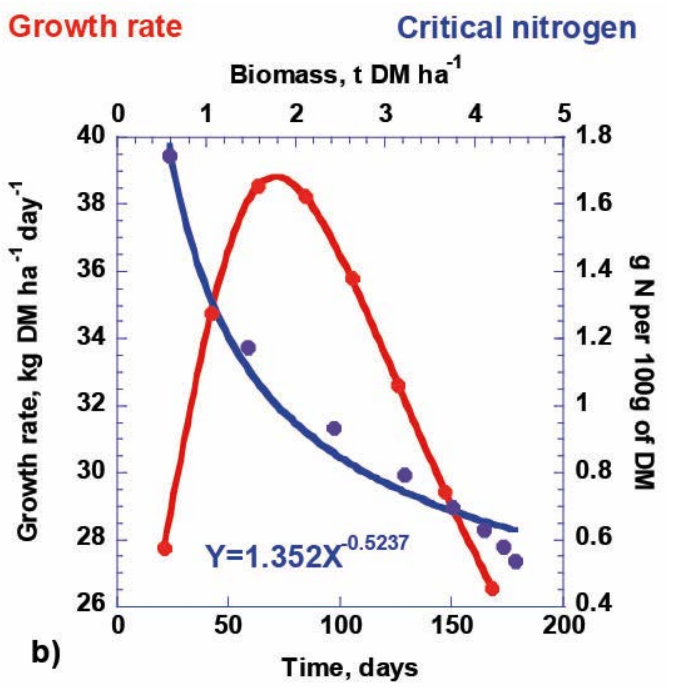

Figure 4. Growth rate and Nc of the Roxo cultivar: a) Fertilized b) Not Fertilized.

Growth rate

Critical nitrogen

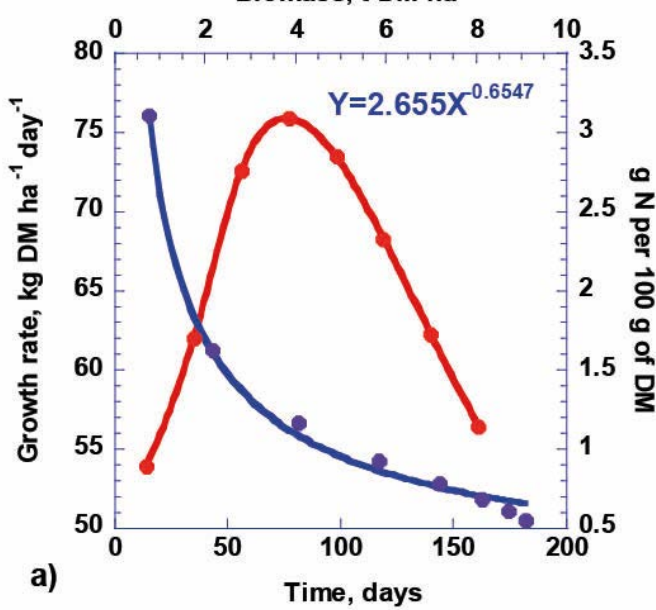



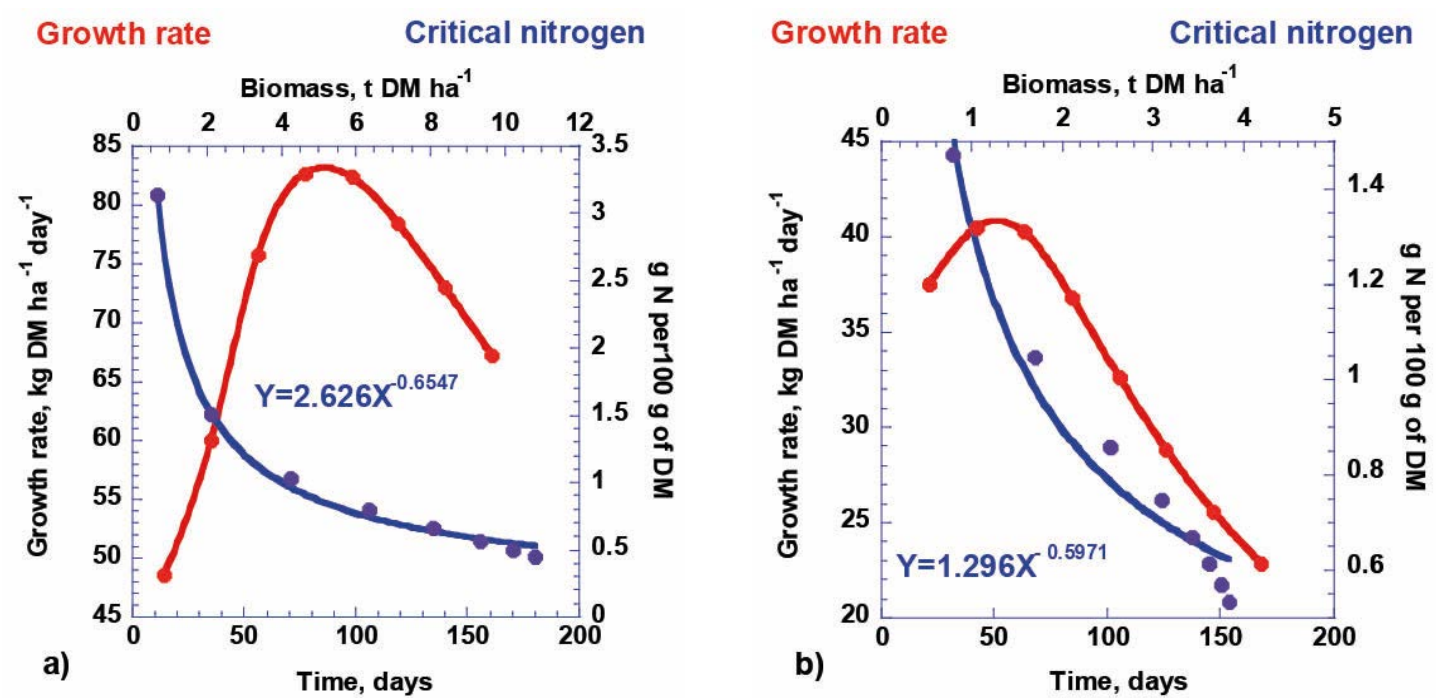

Figure 5. Growth rate and Nc of the cultivar Taiwan: a) Fertilized b) Not Fertilized.

in the rainy season in the Mexican tropics, they have $\mathrm{Nc}$ of $2.6 \mathrm{~g}$ of $\mathrm{N}$ per $100 \mathrm{~g}$ of $\mathrm{DM}$ in $\mathrm{t} \mathrm{MS} \mathrm{ha} \mathrm{M}^{-1}$. The $\mathrm{Nc}$ values of this study were lower than those reported by Lemaire and Gastal (1997) who mentioned that the Nc values are $3.6 \mathrm{~g}$ of $\mathrm{N}$ per $100 \mathrm{~g}$ of DM in tropical fodders. These differences may be due to factors, such as the high DM production of these cultivars of C.pupureus, the deficiency or lack of nitrogen, water stress, among other factors. They also presented a decrease in the N content, with an average of $59 \%$ in the fodder, which caused that in all cultivars, except Taiwan, more nitrogen was extracted from the soil due to the deficit in the dosage or contribution of mineral nitrogen.

Regarding the growth rates, cultivars CT-115 and Elefante registered their maximum growth before applying 35\% of the rest of the nitrogen, that is, it was before $56 \mathrm{~d}$ of age, in contrast to King Grass, Roxo and Taiwan whose maximum growth was recorded at $77 \mathrm{~d}$ of age. These results suggest applying the fertilization dose before its maximum growth occurs. In antecedents to the thresholds established by Duru et al. (1997) for the management of the $\mathrm{NNI}$ of fodders, Figure $6 \mathrm{a}$ shows where the NNI was higher than 1.0 in the first $14 \mathrm{~d}$, which indicates that the studied cultivars had excess $N$ for their growth. However, from 35 d of age the NNI of cultivars King Grass, CT-115, Elefante, Roxo and Taiwan, these values were located in the classification of nitrogen deficient $(\mathrm{NNI}<0.8)$. With the results obtained, the application of nitrogen can be planned to obtain the highest efficiency; since, as it was observed, at the beginning of the growth nitrogen is present in excess and after day 35 of growth the deficiencies appear.
Figure $6 \mathrm{~b}$ shows the NNI behavior of cultivars CT-115, Elefante, King Grass, Roxo and Taiwan, during growth without application of the fertilizer. The NNI data are less than 0.8, therefore in accordance with the threshold described by Duru et al. (1997), it is in deficiency. This is demonstrated by the low Nc value of $1.14 \mathrm{~g}$ of $\mathrm{N}$ per $100 \mathrm{~g}$ of DM and low growth rates and production of dry matter. Although the NNI data in the cultivars studied during the first $35 \mathrm{~d}$ of age are sufficient, the dose used did not reach the fodder requirements, since they extracted $\mathrm{N}$ from the soil to complement growth and DM production.

\section{CONCLUSIONS}

The critical nitrogen content of the cultivars of Cenchrus purpureus fertilized was $2.6 \mathrm{~g}$ of $\mathrm{N}$ per 100 $\mathrm{g}$ of DM to produce $1.0 \mathrm{t} \mathrm{DM} \mathrm{ha}^{-1}$ and growth rates up to $112 \mathrm{~kg}$ of DM per day in $77 \mathrm{~d}$. The NNI values were higher than 0.8 during the first $56 \mathrm{~d}$, which is considered good nutritional status, but considering the data of the unfertilized group it is considered that these cultivars require a greater amount of $\mathrm{N}$ in order not to extract the complement from the soil. This demonstrates the usefulness of these agronomic tools such as Nc and NNI to help diagnose the $N$ requirements of said fodders, and thus be able to make adjustments to fertilization and its frequency of application.

\section{ACKNOWLEDGMENTS}

The collaboration of Dr. Isaías Lopez Guerrero, who began and supported this research, as well as the evaluation of Cenchrus purpureus cultivars. 

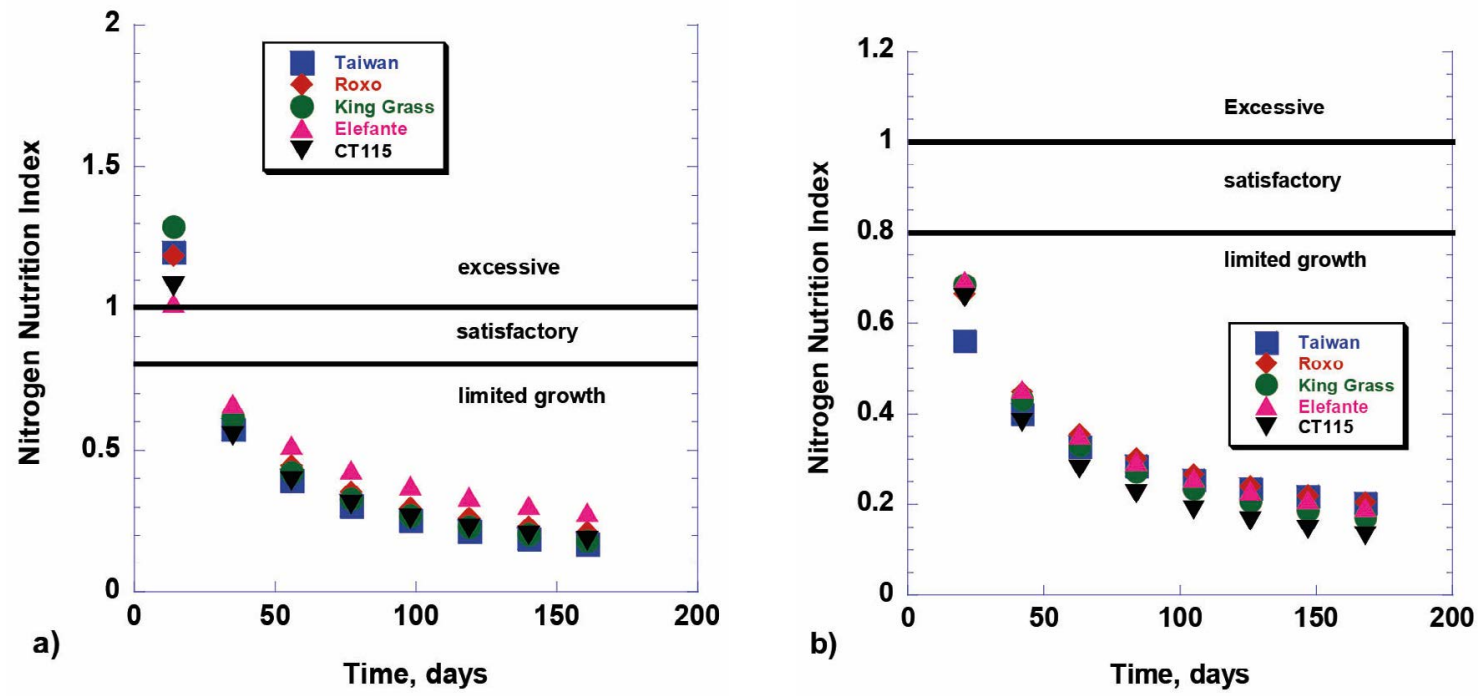

Figure 6. NNI of cultivars of Cenchrus purpureus during growth: a) Fertilized b) Not Fertilized.

\section{REFERENCES}

Agnusdei, M. G., Assuero, S. G., Lattanzi, F. A., \& Marino, M. A. (2010) Critical $\mathrm{N}$ concentration can vary with growth conditions in forage grasses: implications for plant $\mathrm{N}$ status assessment and $\mathrm{N}$ deficiency diagnosis. Nutrient Cycling in Agroecosystems, 88(2), 215-230

Calzada-Marín, J. M., Enríquez-Quiroz, J. F., Hernández-Garay, A. Ortega-Jiménez, E., \& Mendoza-Pedroza, S. I. (2014). Análisis de crecimiento del pasto maralfalfa (Pennisetum sp.) en clima cálido subhúmedo. Revista mexicana de ciencias pecuarias 5(2), 247-260

Colnenne, C., Meynard, J. M., Reau, R., Justes, E., \& Merrien, A. (1998). Determination of a critical nitrogen dilution curve for winter oilseed rape. Annals of botany, 81(2), 311-317

Chemisquy, M. A., Giussani, L. M., Scataglini, M. A., Kellogg, E. A., \& Morrone, O. (2010). Phylogenetic studies favour the unification of Pennisetum, Cenchrus and Odontelytrum (Poaceae): a combined nuclear, plastid and morphological analysis, and nomenclatural combinations in Cenchrus. Annals of Botany 106(1), 107-130

Duru, M., Lemaire, G., \& Cruz, P. (1997). Grasslands. In Diagnosis of the nitrogen status in crops (pp. 59-72). Springer, Berlin, Heidelberg.

Greenwood, D. J., Lemaire, G., Gosse, G., Cruz, P., Draycott, A., \& Neeteson, J. J. (1990). Decline in percentage N of C3 and C4 crops with increasing plant mass. Annals of botany, 66(4), 425 436.

Gonzalez-Dugo, V., Durand, J. L., Gastal, F., \& Picon-Cochard, C. (2005). Short-term response of the nitrogen nutrition status of tall fescue and Italian ryegrass swards under water deficit Australian Journal of Agricultural Research, 56(11), 1269-1276.

INEGI, C. E. (2009). Instituto Nacional de Estadística y Geografía Catálogo de claves de entidades federativas, municipios y localidades

Jeuffroy, M. H., \& Meynard, J. M. (1997). Azote: production agricole et environnement

Juárez-Hernández, J., Bolaños, E. D., \& Reinoso, M. (2004). Content of protein per unit of dry matter accumulated in tropical pastures. Winter. Cuban Journal of Agricultural Science, 38(4), 415-422.
Juárez Hernández, J., Bolaños Aguilar, E. D., \& Chan de la Rosa, I. (2005). Estudio agrofisiológico y nutricional de la producción de materia seca y contenido de proteína en pastos tropicales Universidad Central Marta Abreu de las Villas, Facultad de Ciencias Agropecuarias.

Justes, E., Mary, B., Meynard, J. M., Machet, J. M., \& Thelier-Huché, L. (1994). Determination of a critical nitrogen dilution curve for winter wheat crops. Annals of botany, 74(4), 397-407.

Lemaire, G., \& Salette, J. (1984a). Relation entre dynamique de croissance et dynamique de prelevement d azote pour un peuplement de graminees four-rageres. I Etude de I effet du milieu. Agronomie. 4, 423-430

Lemaire, G., \& Salette, J. (1984b). Relation entre dynamique de croissance et dynamique de prelevement d azote pour un peuplement de graminees four-rageres. II Etude de la variabilite entre genotypes. Agronomie. 4, 431-436.

Lemaire, G., Cruz, P., Gosse, G., \& Chartier, M. (1985). Etude des relations entre la dynamique de prélèvement d'azote et la dynamique de croissance en matière sèche d'un peuplement de luzerne (Medicago sativa L.). Agronomie, 5, 685-692.

Lemaire, G., Gastal, F., \& Plenet, D. (1997). Dynamics of N uptake and $\mathrm{N}$ distribution in plant canopies. Use of crop $\mathrm{N}$ status index in crop modelling. Colloques de l'INRA (France).

Lemaire, G., \& Meynard, J. M. (1997). Use of the nitrogen nutrition index for the analysis of agronomical data. In Diagnosis of the nitrogen status in crops (pp. 45-55). Springer, Berlin, Heidelberg

Lemaire, G., \& Gastal, F. (1997). N uptake and distribution in plant canopies. In Diagnosis of the nitrogen status in crops (pp 3-43). Springer, Berlin, Heidelberg.

Lemaire, G., Jeuffroy, M. H., \& Gastal, F. (2008). Diagnosis tool for plant and crop N status in vegetative stage: Theory and practices for crop N management. European Journal of agronomy, 28(4), 614-624

Minitab, I. (2014). MINITAB release 17: statistical software for windows Minitab Inc, USA, 371

Ramos Sánchez, A. (1985). Logros y aportaciones de la investigación agrícola en el cultivo de forrajes zonas tropicales y subtropicales (No. Folleto 10368). 117 
Reyes-Castro, S., Enríquez-Quiroz, J. F., Hernández-Garay, A. C., Esqueda-Esquivel, V. A., \& Gutiérrez-Arenas, D. A. (2018). Rendimiento de seis cultivares de Cenchrus purpureas (Schumach.) Morrone con potencial para producción de bioetanol. Agroproductividad, 11(5), 56-62.

Rueda, J. A., Ortega-Jiménez, E., Hernández-Garay, A., EnríquezQuiroz, J. F., Guerrero-Rodríguez, J. D., \& Quero-Carrillo, A. R. (2016). Growth, yield, fiber content and lodging resistance in eight varieties of Cenchrus purpureus (Schumach.) Morrone intended as energy crop. Biomass and Bioenergy, 88, 59-65.

Vidal Zepeda, R. (2005). Las regiones climáticas de México 1.2. 2 (No 551.59 V5. Tesis.)

Tilman, D., Cassman, K. G., Matson, P. A., \& Naylor, R. S. Polasky (2002). Agricultural sustainability and intensive production practices. Nature, 418(6898), 671.

Ziadi, N., Brassard, M., Bélanger, G., Cambouris, A. N., Tremblay, N., Nolin, M. C., \& Parent, L. É. (2008). Critical nitrogen curve and nitrogen nutrition index for corn in eastern Canada. Agronomy Journal, 100(2), 271-276

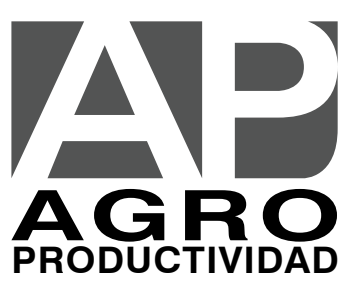

